Економічні науки: збірник наукових праць Луиького національного технічного університету. Серія "Регіональна економіка". Випуск 17 (67). Редкол.: відп. ред. к.е.н., професор І.В. Кривов’язюк. Луцьк: ІВВ Луцького НТУ, 2020. 348 с.

УДК 332.12:336.14

Недопад Г.В., аспірант

Луцький національний технічний університет

\title{
ТЕОРЕТИЧНІ АСПЕКТИ ДОСЛІДЖЕННЯ БЮДЖЕТНОЇ ЕФЕКТИВНОСТІ ТЕРИТОРІЇ
}

У статті розглянуто теоретичні аспекти дослідження бюджетної ефективності території. Притримуючись комплексного підходу, обгрунтовано дану дефініцію за трьома такими аспектами: оціночно-фінансовим аспектом; макроекономічним аспектом; нормативно-цільовим аспектом.

Ключові слова: територія, бюджетна ефективність, місцеві бюджети, фінансова самодостатність, фінансова спроможність території.

\section{Nedopad Hryhorii \\ THEORETICAL ASPECTS TO INVESTIGATION OF BUDGET EFFICIENCY OF THE TERRITORY}

Introduction. One of the key points of our time is the impossibility of local self-government bodies exercising their powers at the expense of their own financial resources. Most of the local budgets of the regions of Ukraine are not provided with their own financial resources in sufficient quantities. Therefore, it seems relevant to search for ways to form a financially powerful base for local self-government. The crucial point in this regard is to ensure the budgetary efficiency of the territories. The purpose of this article is to investigate and to prove the theoretical foundations of the budgetary efficiency of the territory. The methodological base of the research was the developments of economic and financial science according to the study of the local budget, budgetary policy. Results. The complexity and multidimensionality of the category «budgetary efficiency» explains the presence in the modern financial and economic literature of many approaches to understanding its content. Following an integrated approach, as well as systematizing, generalizing and improving the approaches of scientists, from our point of view, the budget efficiency of the territory: 1) is a quantitative and qualitative assessment (indicator) of the effectiveness of management of local budgets of the territory (assessment and financial aspect);2) the result of the effectiveness of local executive authorities and local self-government bodies, the success of the functioning of business entities (normative-target aspect); 3 ) it is a factor, catalyst and prerequisite for the growth of GRP, and therefore, in general, the financial viability of the territory, as well as the social, economic and environmental development of the territory, the modernization and capitalization of its economy (macroeconomic aspect). Conclusion. Therefore, in a general sense, budgetary efficiency is a synthesized integral indicator of the activities of territorial authorities (local governments) in the formation, distribution 
Економічні науки: збірник наукових праць Луиького національного технічного університету. Серія "Регіональна економіка". Випуск 17 (67). Редкол.: відп. ред. к.е.н., професор І.В. Кривов’язюк. Луцьк: ІВВ Луцького НТУ, 2020. 348 с.

and use of budgetary funds for socio-ecological and economic goals of a strategic and tactical nature. This approach to interpretation broadens the content of the category of «budget efficiency of the territory».

Key words: territory, budgetary efficiency, local budgets, finance selfsufficiency, budget sufficiency of the territory.

Недопад Г.В.

\section{ТЕОРЕТИЧЕСКИЕ АСПЕКТЫ ИССЛЕДОВАНИЯ БЮДЖЕТНОЙ ЭФФЕКТИВНОСТИ ТЕРРИТОРИИ}

В статье рассмотрены теоретические аспекты исследования бюджетной эффективности территории. Следуя комплексному подходу, обоснованно данную дефиницию по трем аспектам: оценочно-финансовый аспект; макроэкономический аспект; нормативно-целевой аспект.

Ключові слова: территория, бюджетная эффективность, местные бюджеты, финансовая самодостаточность, финансовая состоятельность территории.

Постановка проблеми у загальному вигляді і її зв'язок 3 важливими науковими та практичними завданнями. Однією із ключових проблем сьогодення $є$ неспроможність виконання органами місцевого самоврядування владних повноважень за рахунок власних фінансових ресурсів. У більшості місцеві бюджети Волинської області та й інших регіонів України незабезпечені власними фінансовими ресурсами у достатніх обсягах. Тому безумовно й беззаперечно актуальним вбачається пошук шляхів формування фінансово потужної база для місцевого самоврядування. Ключовим моментом при цьому розглядається забезпечення бюджетної ефективності територій.

Аналіз останніх досліджень, у яких започатковано вирішення проблеми. Науково-теоретичні аспекти окресленої проблематики активно й безупинно досліджуються вітчизняними й іноземними науковцями. Зокрема, висвітленню теоретичних, методичних та прикладних питань управління бюджетами територій присвячено праці вітчизняних учених i економістів таких, як Вахович І., Василик О., Васютинська Л., Возняк Г., Дем'янишин В., Карлін М., Кізима Т., Ковалюк О., 
Економічні науки: збірник наукових праць Луиького національного технічного університету. Серія "Регіональна економіка". Випуск 17 (67). Редкол.: відп. ред. к.е.н., професор І.В. Кривов'язюк. Луиьк: ІВВ Луцького НТУ, 2020. 348 с.

Козоріз М., Опарін В., Павлюк К., Сторонянська I., Тарангул Л., Чумаченко М. та багатьох інших [1-6]. Беззаперечно, дослідження учених є вагомим внеском і основою подальшого розвитку теоретико-методичних і прикладних засад забезпечення бюджетної ефективності територій. Разом з тим, у науковій фінансово-економічній літературі спостерігаються певні розбіжності у концептуальних і методичних підходах науковців до обгрунтування окремих аспектів у зазначеній проблематиці.

Цілі статті. Так, основна ціль дослідження полягає в 3'ясуванні концептуальних засад бюджетної ефективності території. Застосування науково-обгрунтованих, насамперед, концептуальних, а в подальшому і методичних засад визначення бюджетної ефективності території дозволить отримати органам влади інформацію про ефективну імплементацію бюджетних процесів і управління бюджетною сферою території.

Виклад основного матеріалу дослідження 3 повним обгрунтуванням отриманих наукових результатів. Насамперед встановимо якісне визначення категорії «бюджетна ефективність території», щоб у подальшому мати підгрунтя для кількісної її визначеності.

«В макроекономічному сенсі «ефективність»є поняттям відносним, оскільки приймається до уваги порівняння (як мінімум двох) станів добробуту, пов'язаних 3 алокацією суспільних благ» [1, с. 46].

Підкреслюючи багатогранність та багатоаспектність категорії «ефективність», цілком закономірно й логічно, що бюджетна ефективність території також $\epsilon$ складною i багатовимірною категорією. Складність і багатоаспектність категорії «бюджетна ефективність» пояснюе наявність в сучасній фінансово-економічній літературі безлічі підходів до розуміння іiі змісту. Разом 3 тим, очевидно, що безупинний розвиток суспільства вносить корективи у змістове наповнення, критерії і параметри оцінювання ефективності.

Бюджетну ефективність можна розглядати на рівні конкретного процесу, окремого проекту, програми, суб'єкта 
Економічні науки: збірник наукових праць Луиького національного технічного університету. Серія "Регіональна економіка". Випуск 17 (67). Редкол.: відп. ред. к.е.н., професор І.В. Кривов'язюк. Луиьк: ІВВ Луцького НТУ, 2020. 348 с.

господарювання, виду економічної діяльності, території, країни тощо.

Проаналізовані розуміння вчених-економістів щодо об'єктів їх досліджень, які тісно пов'язані із бюджетною ефективністю територій, дозволяють виокремити декілька концептуальних підходів до трактування бюджетної ефективності: економічного, управлінського, оціночного, цільового, фінансового, макроекономічного. Загалом науковці під бюджетною ефективністю територій розуміють наступне:

- результат управління місцевими бюджетами;

- якісну характеристику бюджетного процесу;

- відповідність фактичних показників виконання місцевих бюджетів за доходами і видатками плановим;

- причинно-наслідкові зв'язки між досягнутими результатами (обсягами й приростом валового регіонального продукту) та процесами формування й використання бюджетних коштів;

- показник результативності й якісного виконання повноважень органами місцевого самоврядування;

- задоволеність суспільства роботою місцевих органів виконавчої влади та органів місцевого самоврядування;

- співвідношення досягнутих результатів (отриманих вигод) із обсягами витрачених бюджетних коштів;

- спроможність досягнення намічених цілей та виконання планових показників і бюджетних програм;

- здатність території організувати бюджетний процес таким чином, щоб показники його результатів були вищими, ніж у попередньому періоді та на рівні або й вище, ніж у інших територій.

Притримуючись комплексного підходу, а також систематизуючи, узагальнюючи й вдосконалюючи підходи вчених, з нашої точки зору, бюджетна ефективність території:

- це кількісно-якісна оцінка (показник) результативності управління місцевими бюджетами території (оціночнофінансовий аспект); 
Економічні науки: збірник наукових праць Луиького національного технічного університету. Серія "Регіональна економіка". Випуск 17 (67). Редкол.: відп. ред. к.е.н., професор І.В. Кривов’язюк. Луцьк: ІВВ Луцького НТУ, 2020. 348 с.

- цее результат дієвості місцевих органів виконавчої влади й органів місцевого самоврядування, успішності функціонування суб'єктів господарювання (нормативноиүільовий аспект);

- це фактор, каталізатор і передумова росту ВРП, а тому і загалом фінансової спроможності території, а також соціального, економічного й екологічного розвитку території, модернізації і капіталізації іiі економіки (макроекономічний аспект).

Бюджетна ефективність території як кількісно-якісна синтезована оцінка (показник) результативності управління місцевими бюджетами території інтегрує означену ефективність на всіх рівнях соціально-економічної системи території. Бюджетну ефективність можна розглядати для консолідованого бюджету або для бюджетів різних рівнів. Бюджетна ефективність території або регіону, як адміністративнотериторіальної одиниці країни, синтезує:

- бюджетну ефективність районів регіону;

- бюджетну ефективність усіх ОТГ регіону.

Досліджуючи взаємодію та взаємозалежність компонентів системи, варто розглянути їх упорядкованість, ієрархічність. Характеризуючи систему бюджетної ефективності території, основою її упорядкованості є ієрархія таких підсистем:

- ефективність бюджетних програм;

- ефективність бюджетного процесу;

- ефективність бюджетного менеджменту;

- ефективність бюджетної політики.

Бюджетна ефективність території як результат дієвості місцевих органів виконавчої влади й органів місцевого самоврядування загалом зводиться до ефективності трьох ключових бюджетних процесів:

1) ефективність формування бюджетних коштів, що полягає у достатності їх формування задля збалансування бюджетних доходів і видатків; 
Економічні науки: збірник наукових праць Луиького національного технічного університету. Серія "Регіональна економіка". Випуск 17 (67). Редкол.: відп. ред. к.е.н., професор І.В. Кривов’язюк. Луцьк: ІВВ Луцького НТУ, 2020. 348 с.

2) ефективність розподілу бюджетних коштів, що визначається оптимальними i раціональним напрямами їх розподілу задля розвитку території;

3) ефективність використання бюджетних коштів на соціально-економічні та екологічні цілі розвитку території.

Так, бюджетна ефективність охоплює повний бюджетний цикл.

Бюджетну ефективність як фактор, каталізатор $i$ передумову соціо-еколого-економічного розвитку території варто розглядати у кореляції і шляхом співставлення з рівнем іiі соціально-економічного розвитку. У даному контексті вбачається доцільним розмежування таких різновидів бюджетної ефективності:

- економічна (в т.ч. галузева) бюджетна ефективність;

- соціальна бюджетна ефективність (базується на відповідності видатків місцевих бюджетів соціальним потребам, інтересам населення території, належною підтримкою малозабезпечених i соціально незахищених категорій населення);

- екологічна бюджетна ефективність.

Висновки. Підводячи підсумки проведеної наукової дискусії, у загальному розумінні бюджетна ефективність - це синтезований інтегральний показник діяльності органів територіальної влади (органів місцевого самоврядування) щодо формування, розподілу та використання бюджетних коштів на соціо-еколого-економічні цілі стратегічного та тактичного характеру. Такий підхід до тлумачення розширює змістовність категорії «бюджетна ефективність території».

\section{Список бібліографічного опису}

1. Васютинська Л.А. Система видатків бюджету в умовах розвитку програмно-цільового управління: Монографія. Одеса: Друк-Південь, 2014. 192 c. URL: http://dspace.oneu.edu.ua/jspui/bitstream/123456789/3075/1/Система\%20видатків\%2 0бюджету\%20в\%20умовах\%20розвитку\%20програмно\%20цільового\%20управління.pdf (дата звернення: 10.09.2020).

2. Вахович I.M., Камінська І.М. Фінансова спроможність регіону: діагностика та механізми забезпечення: монографія. Луцьк: Надстир'я, 2009. $400 \mathrm{c}$. 
Економічні науки: збірник наукових праць Луиького національного технічного університету. Серія "Регіональна економіка". Випуск 17 (67). Редкол.: відп. ред. к.е.н., професор І.В. Кривов’язюк. Луцьк: ІВВ Луцького НТУ, 2020. 348 с.

3. Вахович І.М., Ропотан І.В. Критерії ефективності бюджетної політики регіону. Економічні науки. Серія: Економіка та менеджмент. 2012. Вип. 9(2). С. 81-88. URL: https://core.ac.uk/download/pdf/147041157.pdf (дата звернення: 10.09.2020).

4. Дем'янишин В.Г., Кізима Т.О. Регіональна бюджетна політика: теоретична концептуалізація та перспективи розвитку. Регіональна економіка. 2016, №4. $\quad$ C. $91-99 . \quad$ URL: http://re.gov.ua/re201604/re201604_091_DemyanyshynVH,KizymaTO.pdf （дата звернення: 10.09.2020).

5. Сергієнко Л.К. Ефективність державної бюджетної політики у контексті інтеграційних процесів. Науковий вісник Міжнародного гуманітарного університету. Серія: Економіка і менеджмент. 2015. Вип. 11. C. 255-259. URL: http://nbuv.gov.ua/UJRN/Nvmgu_eim_2015_11_58 (дата звернення: 10.09.2020).

6. Сторонянська І.3., Козоріз М.А., Давимука С.А., Возняк Г.В. та ін. Управління фінансовими ресурсами місцевих бюджетів львівщини: проблеми та напрями підвищення ефективності / НАН України. Інститут регіональних досліджень; за ред. д.е.н., проф. І.З. Сторонянської. Львів. 2013. 93 с.

\section{References}

1. Vasiutynska, L.A. (2014). Systema vydatkiv biudzhetu v umovakh rozvytku prohramno-tsilovoho upravlinnia [The system of budget expenditures in the development of program-targeted management]. Odesa: Druk-Pivden, $192 \mathrm{p}$. Retrieved from http://dspace.oneu.edu.ua/jspui/bitstream/123456789/3075/1/Система\%20видатків\%2 0бюджету\%20в\%20умовах\%20розвитку\% 20програмно\%20цільового\%20управління.pdf (accessed 10 November 2020). [in Ukrainian].

2. Vahovych, I.M., Kaminska I.M. (2009). Finansova spromozhnist rehionu: diahnostyka ta mekhanizmy zabezpechennia [Financial capacity of the region: diagnosis and mechanisms to ensure]. Lutsk: Nadstyrria. 400 p.

3. Vahovych, I.M., Ropotan, I.V. (2012). Kryterii efektyvnosti biudzhetnoi polityky rehionu [Criteria for performance budget policy area]. Ekonomichni nauky. Seriia: Ekonomika ta menedzhment, vol. 9(2), pp. 81-88. Retrieved from https://core.ac.uk/download/pdf/147041157.pdf (accessed 10 November 2020). [in Ukrainian].

4. Demyanyshyn, V.H., Kizyma, T.O. (2016). Rehionalna biudzhetna polityka: teoretychna kontseptualizatsiia ta perspektyvy rozvytku [Regional budget policy: theoretical conceptualization and development prospects]. Rehionalna ekonomika, no. 4, pp. 91-99. Retrieved from http://re.gov.ua/re201604/re201604_091_DemyanyshynVH,KizymaTO.pdf (accessed 10 November 2020). [in Ukrainian].

5. Sergienko, L.K. (2015). Efektyvnist derzhavnoi biudzhetnoi polityky u konteksti intehratsiinykh protsesiv [Effectiveness of the state fiscal policy in the context of the integration processes]. Naukovyi visnyk Mizhnarodnoho humanitarnoho universytetu. Seriia: Ekonomika i menedzhment, vol. 11, pp. 255- 
Економічні науки: збірник наукових праиь Луиького національного технічного університету. Серія "Регіональна економіка". Випуск 17 (67). Редкол.: відп. ред. к.е.н., професор І.В. Кривов’язюк. Луцьк: ІВВ Луцького НТУ, 2020. 348 с.

259. Retrieved from http://nbuv.gov.ua/UJRN/Nvmgu_eim_2015_11_58 (accessed 10 November 2020). [in Ukrainian].

6. Storonianska, I.Z., Kozoriz, M.A., Davymuka, S.A., Vozniak, H.V. (2013). Upravlinnia finansovymy resursamy mistsevykh biudzhetiv lvivshchyny: problemy ta napriamy pidvyshchennia efektyvnosti [Management of financial resources of local budgets of Lviv region: problems and directions of efficiency increase]. Lviv: NAN Ukrainy. Instytut rehionalnykh doslidzhen [NAS of Ukraine. Institute of Regional Research], 93 p. [in Ukrainian]. 